\title{
Where Codes Meet: On the Literary Uses of Iconic Signs
}

DO170.18318/td.2015.en.2.18

1.

Despite its solid grounding in the field of semiotically oriented poetics and its recent surge in popularity thanks to cognitive linguistics, the category of iconicity is not a homogeneous one and, in the literature on literature, encompasses a variety of incommensurable areas of problems. ' In the most traditional and perhaps somewhat old-fashioned view, iconicity is equated with imagery and with the capacity that words have to form illustrative images that stimulate the sensibility of the receiver. ${ }^{2}$

1 Examples of the growing interest in the phenomenon of iconicity, and a testimony to the variety of ways in which this category is understood, can be found in the book series /conicity in Language and Literature (eds. Olga Ficher and Max Nänny, Form Miming Meaning (Amsterdam, Philadelphia: Benjamins, 1999); The Motivated Sign, eds. Olga Fischer and Max Nänny, (Amsterdam, Philadelphia: Benjamins, 2001); From Sign to Singing, eds. Wolfgang Müller and Olga Fisher (Amsterdam, Philadelphia: Benjamins, 2003). For a discussion of various interpretations of the same term and a study of its corresponding phenomena by a Polish author, see Zofia Mitosek, e.g., "Ikoniczność" and "Słowo ikoniczne?," in Mimesis. Zjawisko i problem (Warszawa: Wydawnictwo Naukowe PWN, 1997).

2 See, for example, Zdzisława Kopczyńska, "Malowanie słowami," in lęzyk a poezja (Wrocław: Zakład Narodowy im. Ossolińskich, 1976); ed. Agnieszka Morawińska Słowo i obraz (Warszawa, 1982); Barbara

\section{Grzegorz}

Grochowski works

in the Institute of

Literary Studies at

the Polish Academy

of Sciences, doing research in the fields of poetics, genres and discourse. He is the author of a book on text hybrids and co-author of the dictionary of Cultural Studies. He is a member of the editorial board of the journal "Teksty Drugie." 
Meanwhile, academics subscribing to the ideas of structuralism (among them Roman Jakobson, to name but one) emphasised the problem of motivation in the poetic sign, analysing the artistic operations and strategies that lead to the transformation of arbitrary symbols into recognizable counterparts to extratextual phenomena. ${ }^{3}$ In the study of literary communication, it is iconicity as mimetic formalism, understood as the "quotationality" of statements, that achieved the most privileged position. ${ }^{4}$ In this case, the subject of study was the relationship of likeness shared by given segments of a literary narrative and the textual models of certain utilitarian texts which they imitated. Finally, an issue that enjoys great interest, chiefly due to the influence of cognitivism, is the diagrammaticity of statements, analyzed in their myriad aspects and different textual levels. ${ }^{5}$ It is this final matter, admittedly, that offers the most promising perspectives, as it applies to both utilitarian and artistic texts, is manifested at the local and global levels (i.e. the syntax of a sentence and the overall composition of the text), and encourages studies on empirical linguistic data as well as reflections on the perception of the receiver, and on the mechanisms by which one picks up various analogies and parallels.

While I appreciate the significance of the above perspectives and wish to state my particular sympathy to the final viewpoint, I would also like to point out another issue and examine one more possible approach to the phenomenon of iconicity in literature. I am referring not to the "iconic word," 6 in its various senses, but to the use of strictly iconic signs in linguistic messages: in other words, the topic of iconicity in literature, rather the iconicity of literature itself. The scope of this article will thus exclude

Sienkiewicz, "Literackie 'teorie widzenia" (Poznań, 1992); Seweryna Wysłouch, "O malarskości literatury ${ }_{i}{ }^{\prime}$ in Literatura i semiotyka (Warszawa: Wydawnictwo Naukowe PWN, 2001).

3 Examples include the observations on the symbolism of sounds and the multi-leveled motivation of poetic signs formulated in the seminal work by Roman Jakobson, "Linguistics and Poetics, ${ }_{r}$ in Twentieth-Century Literary Theory, ed. Ken Newton (London: Macmillan Education UK, 1997).

4 See, for example, Maria Renata Mayenowa, "Pojęcie wyrażenia cudzysłowowego a sytuacja komunikacyjna literatury," in Poetyka teoretyczna (Wrocław: Ossolineum, 1974); Janusz Lalewicz, "Mimetyzm formalny i problem naśladowania w komunikacji literackiej," in Tekst i fabuła, eds. Czesław Niedzielski and Janusz Sławiński (Wrocław: Ossolineum, 1979); Michał Głowiński, "Mimesis językowa w wypowiedzi literackiej, ${ }^{, ~ P a m i e ̨ t n i k ~ L i t e r a c k i ~} 4$ (1980).

5 See, for example, Iconicity in Syntax, ed. John Haiman (Amsterdam, Philadelphia: Benjamins, 1985); Anna Duszak, "Tekst naturalny," in Tekst, dyskurs, komunikacja międzykulturowa (Warsaw: Wydawnictwo Naukowe PWN, 1998); Kognitywne podstawy języka i językoznawstwa, ed. Elżbieta Tabakowska (Kraków: Universitas, 2001). 
such crucial aspects of the relationship between the verbal and the visual as description, elkphrasis, intersemiotic translation, the aestheticisation of the linguistic sign (as represented by carmina figurata and calligrams, for example), and the textual equivalisation of the image. I will not analyze situations in which a piece of literature refers to a certain work of visual art as a theme, be it alluded to or explicitly named. I would like to focus this study on units that might be described, to use a concept from the field of art history, as "semantic enclaves" appearing in contemporary artistic texts. Mieczysław Wallis, from whom I have borrowed this term, uses it to describe "such a part of a work of art that is composed of signs of a different type, or belonging to a different system, than the work as a whole,"7 and thus comprises a certain relatively independent, complete constituent that follows its own rules and presents its own semantic potential. As an example of such a phenomenon, Wallis mentions verba visibilia, or writing placed in paintings, from the banderoles bearing dialog or sententiae featured on Medieval canvases, to the inscriptions pasted by Pablo Picasso and Max Ernst onto their avant-garde collages. The analysis and comparison of many diverse examples demonstrates the dynamic nature of the relationship between the image and word in different eras, cultural formations, and artistic styles. Depending on the time and place in which a particular work was created, we observe a change in the form of "quoting," or the combining of incommensurable signs, the hierarchies governing the relationships between codes, the ideological and aesthetic justifications for the use of inscriptions, and the functions ascribed to such semantic interjections.

I am, however, interested in the opposite situation, one that nevertheless refers to the relationship between the word and the image: namely, such works in which images - not in the sense of poetic visions, rhetorical figures, or realist descriptions, but as literal drawings, maps, or diagrams - are introduced into the literary text. The presence of such visual elements in a book has traditionally been associated with the category of illustration, which serves to facilitate the understanding of messages conveyed through the use of language; it is an ornament intended to increase the aesthetic attractiveness of a given volume. In a similar understanding, the image is associated mainly with popular publications, didactic or utilitarian literature (including, for example, cookbooks and travel guides), as well as children's books. It is safe to say that the phenomenon of illustration has rarely captured the interest of scholars in the fields of textual linguistics, literary theory, or even semiotics, likely owing to the optional nature of the relationship between the

7 Mieczysław Wallis, "Napisy w obrazach," in Sztuki i znaki. Pisma semiotyczne (Warszawa: Państwowy Instytut Wydawniczy, 1983), 191. 
verbal and the visual in such arrangements. ${ }^{8}$ The matter becomes somewhat more complicated when we approach the subject of illustrations created by the very author of the book. This raises the rather obvious question of the degree to which we are to treat them as an irremovable part of the work, as

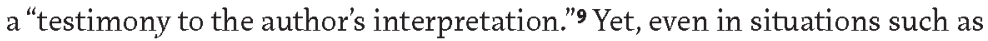
the above, the answer is frequently in the negative, as evident in the common editorial practice of excluding such drawings from the canonical version of a given text. ${ }^{10}$

In contemporary literature, however, and particularly in prose, there are instances of such works in which the function of the image is not limited to illustrating the antecedent, autonomous linguistic message. We may thus posit that the semiotic status of visual signs in literary communication is changing before our eyes. The image is ceasing to be an aesthetic addition that serves merely to illustrate the contents of the verbal layer, and is becoming an integral part of the narrative or lyrical monologue, taking its place in the specific relationship of communication and becoming another part of the various tensions involved in the creation of meaning. The phenomenon I intend to examine should thus be considered a special case - perhaps a somewhat peculiar yet significant and informative one - within the broader problematics described in terms of the correspondences, relatedness, influence, transpositions, and interferences in art. ${ }^{11}$ It should also be noted that the last category seems most appropriate in the given context, as we are concerned not with the relationships that emerge from the comparison of the inherent qualities of individual disciplines, but rather with the consequences of an incidental juxtaposition, one that leads

8 An interesting attempt to describe such ties can be found in the study by Františsek Daneš, "Text a jeho ilustrace, "Slovo a slovesnost 56 (2009): 174-189. See also Wysłouch, "Tekst i ilustracja," in Literatura a sztuki wizualne (Warszawa: Wydawnictwo Naukowe PWN, 1994). It is likely apparent that we are now approaching the matters that constitute the subject of our attention.

9 Wysłouch, "Ilustracja autorska - casus Brunona Schulza," Teksty Drugie 5 (1992): 120.

10 For an examination of this topic, see, for example, Wysłouch, "Tekst i ilustracja"; Jerzy Szyłak, Poetyka komiksu. Warstwa ikoniczna i językowa (Gdańsk: słowo/obraz terytoria, 2000), 154-157.

11 See, for example, Oskar Walzel, "Wzajemne naświetlanie się sztuk, "in Teoria badań literackich zagranica, ed.Stefania Skwarczyńska, vol. 2, part 1 (Wrocław: Wydawnictwo Literackie, 1974); Teresa Cieślikowska, Janusz Sławiński, eds., Pogranicza i korespondencje sztuk (Wrocław: Zakład Narodowy im. Ossolińskich, 1980); Mieczysław Porębski, Obrazy iznaki (Kraków: 1986); Mary Anne Caws, The Art of Interference (Princeton: Princeton University Press, 1990); Maryla Hopfinger, Wlaboratorium sztuki XX wieku. O rolisłowa iobrazu (Warszawa: Wydawnictwo Naukowe PWN, 1993); Adam Dziadek, Obrazy iwiersze. Zzagadnień interferencji sztuk w polskiejpoezji współczesnej (Katowice: Wydawnictwo UŚ, 2004). 
to the overlapping of two different systems of signs within the space of a single text. ${ }^{12}$

Of course, the phenomenon in question is not an entirely new one, nor some great revolution in how statements are formed, but rather a growing trend. Measures of this sort remained rare for several decades and may have appeared to be an isolated form of extravagance or a one-off experiment that failed to become a widespread or recognizable trend. Among the examples that achieved the privileged status of an isolated endeavor motivated by the particular poetics and theme of the work were, in the 1940s, the use of original illustrations in Antoine de Saint-Exupéry's The Little Prince, and, somewhat later, in the 1970s, the visual depictions inserted into the narrative of Kurt Vonnegut's Breakfast of Champions. A separate (and rather small) group comprised artists who were professional drawers, caricaturists, and illustrators such as Roland Topor and Edward Gorey, who attempted to use their experience in the visual arts to create experimental and humorous narrative texts (Gorey even went as far as to make triviality one of the main premises of his aesthetic, known as "Goreyography"). ${ }^{13}$ Noteworthy examples of the use of such strategies in Polish literature can be observed in the achievements of writers belonging to the milieu known as "young prose," though individual instances can also be found in poetry, even in the output of authors who are not part of the younger generation (these include Witold Wirpsza, author of Komentarz do fotografii [A Commentary on Photographs], which binds, into a single whole, poems, photographs and inscriptions, forming a peculiar paraphrase of the old form of the emblem, and Jacek Durski, whose book Uderza Ziemia [Earth Strikes] can actually be classified as either a poetry book or an album of illustrations). Of course, considering the actual state of affairs, it must be admitted that books of this type remain a minority, paling in comparison - both in terms of their number and popularity - to homogeneous linguistic messages, that is, literature based solely on the written word. Despite the popular conviction about the dominance of the image in contemporary culture, it would be difficult to find an abundance of works displaying such multimedia poetics. This

12 On the subject of the category of interference in art, cf. Dziadek, Obrazy i wiersze, 14-16.

13 Among the younger generation of Polish artists, the one most closely associated with this group would likely be Maciej Sieńczyk, the author of charming Hydriola (Warszawa: Lampa i Iskra Boża, 2005), in which the exaggerated style of both the verbal narrative and the visual layer serve to evoke a grotesque reality that borders on a hallucinatory play of associations, a surreal, macabre story, and a pastiche on old-fashioned popular literature. However, the autonomy of the image is so far-reaching that one doubts whether the work in question can still be considered a literary text. 
is not necessarily a refutation of general, sociological, or anthropological diagnoses regarding the condition of modern civilization. One may assume, for instance, that the dominance of the visual is manifested in the waning social prestige of literature and the concurrent rise of other media, rather than in transformations occurring within literary discourse itself. On the other hand, our general and academic awareness appears to ascribe significant relevance to various multi-coded messages; even among the numerous projects devoted to literary theory, there are vocal opinions critical of the "verbocentrism" of poetics, as well as calls for the creation of a multimedia literary genology or stylistics. ${ }^{14}$ Though works that employ iconic signs remain scarcer than novels or short story collections based exclusively in the medium of the word, even these individual, isolated texts are places in which crucial tensions that dynamise contemporary literature, and even the entire space of social communication, are manifested. There have not yet been any in-depth and thorough theoretical studies devoted to the issue of such intratextual interaction between various signs (despite plenty of notable examinations of certain parts and aspects), nor any attempts to verify general theses through specific analyses, which is why this analysis, which I will attempt to base on specific examples as often as possible, can only be considered a superficial reconnaissance. ${ }^{\mathbf{1 5}}$

\section{2.}

Let us begin by identifying the textual phenomena that are to be interpreted as icons, and by determining the initial semantic potential of such units. As we remember, the iconic sign, according to the definition by Charles $\mathrm{S}$. Peirce, is an element that replaces an object for a certain receiver through its resemblance to the object itself, due to certain features shared with that which it signifies (as in the relationship between the drawing of a horse and

14 See, for example, Wysłouch, "Werbocentryzm - uzurpacje i ograniczenia," in Literatura i semiotyka; Edward Balcerzan, "W stronę genologii multimedialnej," in Genologia dzisiaj, eds. Włodzimierz Bolecki and Ireneusz Opacki (Warsaw: Wydawnictwo IBL PAN, 2000): Ewa Szczęsna, "Opowiadanie i media," Pamiętnik Literacki 2 (2002).

15 There have been many more studies devoted to the various ways of imparting one group of signs with features characteristic of other classes of phenomena, as is the case with the previously-mentioned aestheticization of the word, visible in carmina figurata, for instance, and particularly in concrete poetry (see, for example, Piotr Rypson, Obraz słowa. Historia poezji wizualnej (Warszawa: Akademia Ruchu, 1989); Tadeusz Sławek, Między literami. Szkice o poezji konkretnej (Wrocław: Wydawnictwo Dolnośląskie, 1989); Wysłouch, "Od słowa do ornamentu. Semiotyczne problemy poezji konkretnej," in Literatura i semiotyka). 
the signified horse, to use one of the most frequent and trivial examples). ${ }^{\mathbf{1 6}}$ It is thus sometimes referred to as a representative sign (as its main quality is its capacity to represent through imitation, its ability to actualize selected qualities of the denoted object) or a motivated sign, in contrast to the arbitrary, conventional symbol (which include units of a verbal code, among others). ${ }^{17}$ Such is the role in which drawings are usually included in the text, be they drawn by the author or selected by him (it should be mentioned that not all images can be interpreted as iconic signs, which, by their very nature, often represent abstract meanings, as is the case with the classic example of the "peace dove"). The next group comprises icons that I would tentatively describe as "utilitarian illustrations," or various technical or anatomical cross sections, maps, and plans as well as manuals in which the visual element represents a certain action and illustrates a recommended method of operation. And, finally, though somewhat hesitantly, I would include photographs in this list of visual inserts. One should, of course, keep in mind that the semiotic status of the photograph remains a contentious issue and that even Peirce himself did not treat the photograph as an icon. He believed that the picture, as a product of the optical process of reproduction, retained a direct, physical relationship with its object, and thus, despite the visible likeness, became an indexical mark or situational index..$^{\mathbf{1 8}}$ There are, however, argu-

16 A detailed discussion of Peirce's theses can be found in Hanna Buczyńska-Garewicz, Wartość ifakt. Rozważania o pragmatyzmie (Warszawa: Państwowe Wydawnictwo Naukowe, 1970) and Znak - znaczenie - wartośc. Szkice o filozofii amerykańskiej (Warszawa: Książka i Wiedza, 1975). The epistemological aspects of the concept have been explored in Max Bense, Vermittlung der Realitäten: Semiotische Erkenntnistheorie (Baden-Baden: Agis-Verlag, 1969). For a critical discussion of the category of likeness as the basis for signification, see Włodzimierz Ławniczak "Uwagi o pojęciu znaku ikonicznego," Studia Semiotyczne 2 (1971).

17 One should naturally be aware of the various arguments raised against the premises behind isolating such a category, and particularly of the criticism expressed by Umberto Eco, who regarded the concept of natural likeness as a relic of naive magical consciousness and attempted to prove that the perception of a visual analogy is conditioned upon the mastery of perceptive conventions. Images - according to the quoted line of argument - thus do not constitute a separate class of motivated representations contrasted with arbitrary linguistic signs, but form, together with symbols, a cohesive repertoire of conventionalized signs. However, this does not necessarily entail a rejection of the concept itself: Eco, for example, proposes its reinterpretation, recognizing that the iconic sign refers not to the thing itself, but to its perceptual schema. (Umberto Eco, Nieobecna struktura, trans. Adam Weinsberg, Paweł Bravo (Warszawa: Wydawnictwo KR, 1996), 136). See also Wysłouch, "Znak ikoniczny w koncepcji Umberto Eco - nowatorstwo i niekonsekwencje, "in Literatura i semiotyka. ings. Volume 2 (1893-1913), Peirce Edition Project, ed. S. Pierce (Bloomington: Indiana University Press, 1998), 5-6. 
ments that allow us to lessen the strictness of this ruling to a certain degree. It is worth noting, for example, that the father of pragmatism focused primarily on photographs created with the snap of the shutter, pictures that automatically recorded what happened to appear before the lens, while later artworks often revealed intentional processing, many forms of original interference into the process of automatic exposure, as well as various levels of semiotic transformation of the photographic image, consequently weakening the direct, indexical relationship with the object. ${ }^{19}$ Even if we conclude that such an image is a mechanical copy, a replica of the appearance of an object, rather than its visual representation and a unit of semiosis, it can surely change its semiotic nature when affected by a particular context, used in a certain statement, equipped with communicative intent, and ascribed to a given subjective instance. When integrated into the statement, photographs undoubtedly begin to acquire semantic associations and encourage interpretative activity on the part of the reader, while also indicating the potential object of the reference thanks precisely to this relationship of likeness, accentuating the iconic potential of the images. ${ }^{20}$ Such a broadening of the scope of the term seems in line with the main current of Peirce's semiotics, which links meaning to the pragmatic purpose of the sign and to a dynamic performance, to processual semiosis and the effect of the interpretant, rather than a stable arrangement of systemic relationships. ${ }^{21}$

The issue of the semantic capacity of visual signs has, on multiple occasions, been the object of semantic analysis in the field of literary theory. It has been observed, for example, that of the different varieties of meaning, iconic messages overwhelmingly employ the referential function, or a reference

19 See, for example, Hopfinger, O rolisłowa i obrazu, 69 .

20 This classification has been accepted by some scholars. Mieczysław Wallis, mentioned above, acknowledges that "iconic signs are likenesses in the broadest sense: sculptures, paintings, drawings, illustrations, photographs, and films" (Wallis, "O znakach szczególnych," in Sztuki i znaki, 35; emphasis added). See also, for example, Susan Sontag, On Photography (New York: Farrar, Straus and Giroux, 1977); Krzysztof Olechnicki, Antropologia obrazu. Fotografia jako metoda, przedmiot i medium nauk społecznych (Warszawa: Oficyna Naukowa, 2003); Sławomir Sikora, Fotografia: między dokumentem a symbolem (Izabelin: Świat Literacki, 2004).

Peirce, for instance, admitted that "one and the same sign may be at once a likeness and an indication" ("What Is a Sign?," 8), thus practically paving the way for an understanding of iconicity, indexicality, and symbolism as aspects of the sign that are actualized through reception, rather than using them as separate categories of classification applying to the substantial form of the message. In result, it becomes a feasible and attractive proposal to associate iconicity with the mode of reading and to replace the objective nature of the sign with a question about the decisions made by the subject, as a result of which a given element becomes an icon. 
to the denoted object. For this reason, it may even be assumed that the iconic sign occupies a space somewhere between signifying and representation: while a symbolic sign profiles the indicated object through its name and includes it in a web of recognizable classifications, the iconic sign reproduces the ambivalence of the object, in a sense, not always resolving its actualized categorical membership. It is characterized by a certain suspension between the poles of improvisation and codification. On the one hand, we know that visual messages do not have an unambiguously defined dictionary or grammar, nor do they refer us to a complete repertoire of discrete units or employ a codified set of rules governing selection and combination. Due to their integrity, neither drawings nor photographs can be subjected to rigorous morphological analysis. ${ }^{22}$ On the other hand, it is impossible to make an image mean whatever we want it to (as long as we do not arbitrarily impose on it an entirely external and foreign meaning with the use of an inscription, for instance). Iconic messages, as a number of studies in the field of semiotics have shown, rely on general perceptual codes (though these are not subject to such strict grammaticalization as the linguistic system and rather take the form of nebulous connotative repertoires) that select certain qualities of an object as relevant and crucial to the manner in which its identity is captured. It is precisely this reference to imaginative stereotypes that enables a certain enrichment of the visual signs with more detailed content, while the reduction or elimination of some qualities and the emphasizing of others makes it possible, to a certain degree, to modify the nature of the references by portraying an object in one way or another. Another means through which different shades of meaning can be introduced is the style and composition of the depiction: the use of formulaic imagery, for example, usually leads to the universalization of the reference; by diminishing the features considered to be determinants of negative or positive connotations, one can degrade or elevate an object; meanwhile, in the realm of suprasegmental features, certain visual solutions may carry connotations of precision and accuracy of reproduction or a hurried execution and sketchy portrayal; and, finally, at the compositional level, the placement of an object on either the left or right side of a field suggests either familiarity or newness. ${ }^{23}$ All of these mechanisms, however, rely

22 For more on this subject, see, for example Lalewicz, "Przedstawianie i znaczenie. Próba analizy semiologocznej rysunku (1-2)," Sztuka 4-5 (1979).

23 See, for example, Rudolf Arnheim, Visual Thinking (Berkeley: University of California Press, 1971); Gunther R. Kress, Theo van Leeuwen, Reading Images: The Grammar of Visual Design (London: Routledge, 1996). Though it does not deal specifically with semantic categories, one should also mention the seminal work by Ernst Hans Gombrich, Art and IIlusion: A Study in the Psychology of Pictorial Representation (New York: Pantheon Books, 1960). The works of Roland 
on optional qualities of images and remain rather in the realm of cognitive inclinations or preferences, never achieving the position of obligatory rules and only barely approaching the status of a possible grammar of perception. In result, the icon - according to Umberto Eco - "though recognizable, is always burdened by a certain ambiguity and more readily denotes general things than it does detailed ones." 24

The above-mentioned privileging of references has occasionally led to the questioning of the efficacy with which iconic signs fulfill other communicative purposes. Maria Renata Mayenowa claimed, for example, that a "purely iconic message is incapable of conveying metalinguistic information," which, in her view, was the cause of the "fundamental non-metaphoricality of iconic signs." 25 This assertion might be true if we were to narrow our perspective to encompass only the primary meanings evoked by isolated iconic signs stripped of any communicative context. The question I find most interesting, however, is that of the artistic reinterpretation of visual elements: determining the functions ascribed to them in literary discourse and demonstrating the way in which they are incorporated into the semantic structure of the statement. Undoubtedly the simplest and most basic meaning-forming operation is the recontextualization of the icon, i.e., the placement of the visual sign in an unconventional communicative context, juxtaposing it with a system of expectations geared towards extracting specific messages. ${ }^{26}$ Treated in this manner, even the simplest and most literal picture can absorb figurative, allegorical, and metaphorical meanings. Our perceptual apparatus, when appropriately directed beforehand, demonstrates a great eagerness to find such features of the received message that may turn out to be relevant in a given situation. Of course, in the case of a work of literary art, the role of this regu-

Barthes also occupy an important place in the development of the field (for example "Rhetoric of the Image," trans. Stephen Heath, in Image, Music, Text (New York: Hill and Wang, 1977; Camera Lucida: Reflections on Photography, trans. Richard Howard (New York: Hill and Wang, 1981)).

25 Maria Renata Mayenowa, "Porównanie niektórych możliwości tekstów słownych i wizualnych ikonicznych," in Studia i rozprawy, eds. Anna Axer and Teresa Dobrzyńska (Warszawa: Wydawnictwo IBL PAN, 1993), 176. See also Michał Porębski, "Czy metaforę można zobaczyć?" Teksty 6 (1980).

26 It is worth mentioning here that there exists a general tendency in semiotics to tie the semiotic status of the image to its use in communication. Izydora Dąmbska, for example, claims that "objects that are images of other objects are not eo ipso those objects' signs. [...] Even the images that most closely resemble the objects depicted in them only become signs of those objects when equipped with the ability to indicate, signify, or symbolize them." (Izydora Dąmbska, "O konwencjach semiotycznych," Studia semiotyczne 4 (1973): 38-39. 
latory context is played by the linguistic tissue of the statement, comprising both the propositional meanings of each subsequent verbal sequence as well as the stylistic or genre conventions being actualized in a given work. For this reason, icons used in literary discourse should be treated as non-autonomous signs, regardless of the "communicative elevation of the image." ${ }^{27}$ Once brought to life, they may in certain cases become the active side, reinterpreting or even compromising the message conveyed by the verbal channel, but, in the broader perspective, are subject to strong pressure from the verbal layer of the statement. It is mainly the verbal material that unleashes the semantic potential of the image, gives direction to the processes that create meaning, and remains the superior level of communication, the one that determines the overall character and identity of the message. This structure of dominance was already observed by Peirce, who emphasized that the image, aside from its ability to reference an object, has very few capabilities with regard to the conveyance of information. Thus every act of semiosis must combine iconic, indexical, and verbal signs, but "the complex whole may be called a symbol; for its symbolic, living character is the prevailing one." 28

\section{3.}

This pattern appears to find confirmation even when applied to such radical proposals as the recently published title Produkt polski [Made in Poland] by Sławomir Shuty. ${ }^{29}$ This book, which is one big collage comprising an extensive selection of brief manifests, newspaper clippings, bits of comic strips, questionnaires, drawings, and photographs, nearly straddles the boundary between literary and visual artwork and features surreal humor, often sprinkled with a pinch of dark comedy. The author rarely (if ever) speaks directly, expressisverbis; he employs irony, creates parodies and pastiches, desemanticises words, and autonomises the iconiclayer, but even in this case the verbal layer gives some degree of direction to our reading, both in the broader and narrower scope. Above all else, such elements as the title, the genre clas-

27 Hopfinger, O rolisłowa iobrazu, 57

28 Peirce, "What Is a Sign?," 10 . It is telling that in the case of texts in which the image is substantially dominant, it is often the word that dominates the image in terms of function. For example Zbigniew Kloch ("Słowa i obrazy. Kilka uwag o związkach i zależnościach," Pamiętnik Literacki 4 (1990)), in his analysis of "visual texts" (the painting and collage) assumes that "the meanings of these texts cannot be interpreted without referring to verbal codes and the information conveyed through them" (p. 191) and that to do so requires that "the messages be included in a web of intertextual relations" (p. 193). 
sification ("recycling") verbally hinted at by the author, and his opening remarks in "Wstęp do konsumpcjonizmu" ["Introduction to Consumerism"] constitute a peculiar set of coherent instructions that describe the contents of the tome as a grotesque collection of imaginative clichés symptomatic of the mentality displayed by contemporary Polish society. This is repeated at the level of specific phenomena, where the presence of the verbal label frequently leads to the functional transformation of the icon. This is not to say that any of the inscriptions serve merely to ground, tautologically repeat, or literally explain the meaning of the image. Rather, the verbal sequence plays the role of a catalyst that provokes the reader to formulate semantic hypotheses and triggers a series of associations without achieving the status of authoritative commentary that would unambiguously determine the meaning of a given configuration of signs. The meanings evoked in this manner can diverge significantly from the literal sense of the iconic code, postulated by Mayenowa, which often vacillates towards a quotational message. It seems that the matter of such meanings can be found primarily in a set of connotations embedded in culture and ascribed to the visual conventions in question. There are certain ways of making drawings, illustrations, and diagrams that tend to stabilize within a social practice, as a result of which they often become perceived as synecdoches of their corresponding realms of communication. Selected visual signs thus acquire a resonance that exceeds the relationship of likeness, enabling the emergence of an iconographic order. Such an order, in turn, leads to another reevaluation of the references in the image, because, as Eco observes, "in an iconographic code built upon the iconic, the meanings of the basic code become the signifiers," 30 which connote certain complex, "culturally localised" $\mathbf{3 1}$ configurations of a conventional or even symbolic nature (when treated as an iconogram, the image becomes a sort of heraldic attribute of certain phenomena). Thus, in this case, individual iconic signs are reproduced, quoted, and subjected to recontextualisation in such a manner that they lose their referential dimension, acquiring instead a metatextual quality and operating not so much as icons representing objects, but as emblematic quotes from particular poetics, styles, and registers of discourse (individual pictures evoke associations with the visual style of ad leaflets, technical schematics, illustrated magazines, and kitschy religious pamphlets).

As these theses may sound somewhat abstract, let us attempt to illustrate them with the help of specific passages. At one point in the book, for example,

30 Eco, Nieobecna struktura, 155

31 Ibid., 158. 
we encounter an anachronistic map covering the territory of Poland and its neighboring countries (including part of the collapsing USSR). The arrows drawn through individual areas give the map a strategic air, making it resemble the sorts of illustrations seen in historical atlases, ones depicting the courses of famous historical battles. Only by reading the title and legend do we discover that we are looking at a chart depicting the Flooding [of the region] with cheap clothing from the People's Republic of China and the former USSR, with main outdoor markets as the locations of the landmark battles. It is therefore the linguistic text that determines the reference of the arrangement, while the iconic part - via cultural connotations - adds a humorous, mock-heroic interpretation of the denoted object. Meanwhile, in the miniature Polish Karate, ${ }^{32}$ a series of illustrations depicting a person sitting or standing in various positions, one can find in the plane of denotation a representation of a number of rather simple physical exercises, evoking in the sphere of connotations associations with popular instructions and booklets on health, fitness, and hygiene ${ }^{33}$ :

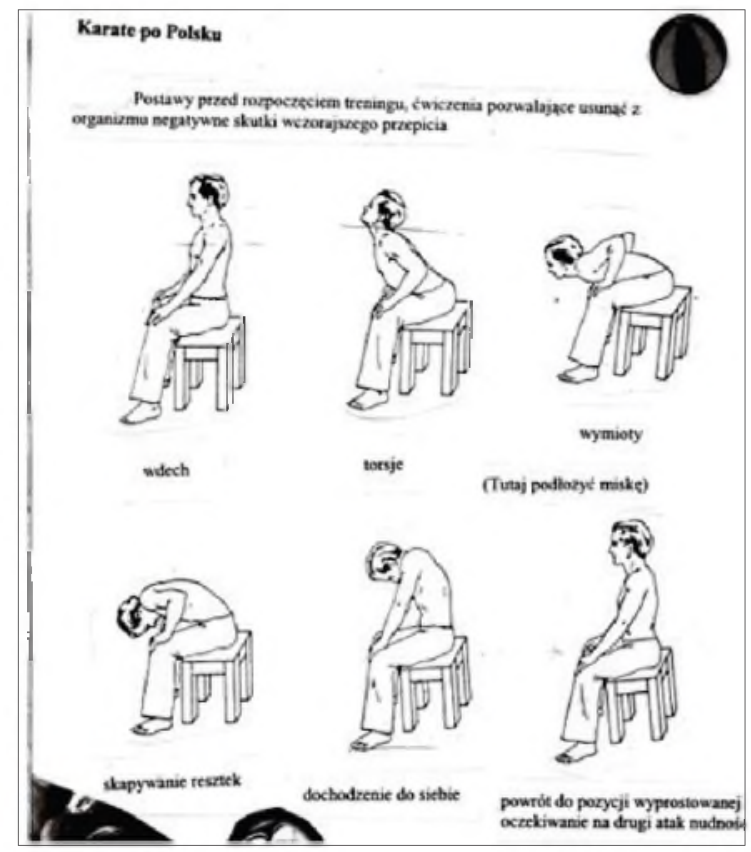

32 Ibid

33 Shuty, Produkt Polski. 
It is only the series of captions that point to an interpretation of the pictographs as illustrations of the suffering experienced by a typical Pole as a result of alcohol overconsumption, allowing us to treat the whole as an ironic and satirical take on stereotypes regarding social mores. Just as I proposed above, we would not find in the presented series of illustrations any subtext associated with Polish customs were it not for the textual complement: the verbal commentary imposes this connection onto the formulaic drawings, compelling us to perceive them in a new context. At the same time, these images are not an inert, malleable body that succumbs to linguistic instructions. It is precisely the connotative potential of the iconic layer that implies the standard, normative nature of the depicted behavior. The analytical disassembling of the simple, trivial - perhaps even embarrassing - action into a series of visual emblems becomes one source of comedy in the statement, compounded further by the contrast between the anticipated dynamism (karate) and the static nature of the depiction. At the same time, the programmatic, instructional nature of publications that use a similar iconographic convention creates the illusion of scientific restraint, making room for an ironic sense of detachment. As a whole, the visual elements serve primarily as characteristic exempla of what we might call individual iconographic subcodes, as prefabricated clichés and connotative media for ingrained social mythologies.

\section{4.}

Shuty's text is incoherent by design and, as such, is paradoxically easy to reduce by grasping the rules behind the collection of clichés, paraphrases, and quotes that govern the entire work. It is, however, possible to integrate more tightly the iconic enclaves with the main stream of the statement by granting them a prominent place in the overall organization of meaning. Such a solution appears to be particularly interesting, as it leads us beyond the borders of the individual sign and enables the observer to reconstruct the meaning-creating strategies inscribed into the text. ${ }^{34}$ I would like to illustrate this possibility by examining Vonnegut's Breakfast of Champions, mentioned above. The book's drawings are woven into the plot and tightly integrated into the linguistic layer (not as a parallel series, but through hypotactic hierarchisation) and are preceded each time by a indexical gesture by the author,

34 Due to limited space, I will merely mention the possibility of the existence of intermediate states, such as when a separate illustrated insert is included in a digressive narrative text. In the novel Podręcznik do Ludzi (Warszawa: W.A.B., 1996), the narrative is interspersed with illustrations depicting tarot cards and reproductions of several paintings, and is preceded by a short series of humorous drawings by the author. 
for example: "It was daytime outside, and there was a clock in the tower. The clock looked like this:

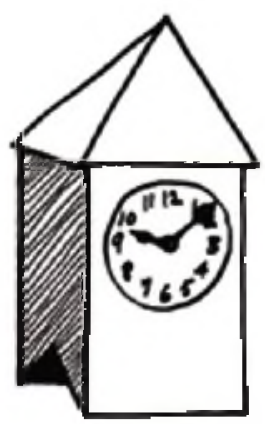

The professor was stripped down to his candy-striped underwear shorts and his socks and garters and his mortar-board..."35

In each of these cases we encounter an obvious duplication of the signification using two codes to represent the same parts of the depicted world. Two things immediately draw our attention: first, the peculiar tautological nature of such an arrangement, one that does not result in a more detailed reference, but is instead limited to an intersemiotic translation of the references; and second, the incidental nature of this measure, or the lack of clearly perceptible criteria according to which the objects subjected to double signification were selected. We cannot say that there is any particular category of phenomena that forced the author to employ visual elements, nor can we indicate any repeatable, typified context that would provoke him to use semiotic pairs.

The ostentatious disruption of the rules of textual autonomy through the complication of the message without providing any tangible increase in information, thus violating Grice's maxim of quantity, prompts us to search for a motivation for this arrangement in the area of implied meanings (not unlike in previous examples, grasping the sense of the configuration requires ingenuity and interpretative activity on the part of the reader). If one seeks such implicit justifications, one should also note the disillusioning effect of such iconic enclaves, in which the clash of codes exposes the conventionality of the story and the materiality of the text (as an arrangement of signifying graphemes), disorganizing the flow of meanings and making room for alternative approaches to the subject. Such parabases, as Paul de Man might say, introduce elements of an ambiguous, ambivalent visual code into the 
coherent linguistic statement, in a sense exposing the gap between the word and the thing, documenting the resistance of factuality against semiosis. The addition of iconic supplements suggests that language, as a narrative tool, is incapable of actually and definitively corresponding to its object, as there remain expanses of malleability and incompleteness stretching out at the margins of the message. ${ }^{36}$ In other words, the arbitrary series of iconic signs in the text of the novel encourages us to suspend our belief in the validity of the categories upon which the narrative is founded and provides a sense of ironic detachment vis-à-vis existing structures, indicating the cognitive limitations of the story. By employing such awkward drawings, Vonnegut in a sense "peels" objects of their meanings, thus distancing himself from culturally-sanctioned signs, which are incapable of conveying critical messages. This is not about the invalidation or destruction of meaning, but rather ironic ambivalence: for a statement to exist, it must confirm and assimilate the model of the world that is ingrained in language, but, at the same, it expresses a critical awareness while retaining a certain margin of leeway indicated by the unpredictable changes in the semiotic register. ${ }^{37}$ From this perspective, the above-mentioned irregularity and incidentalness of the illustrative interjections, which form no series, are justified as a specific form of macrosign, one that repeats, within the arrangement of the text, the haphazardness of being, which eludes the control of the symbolic order. One could say that the subject retains a skeptical distrust of the authority of the discourse, yet fails to provide any opposing order; it is based merely on its inability to fit in, a result of the incidentalness and individuality of this specific being.

And one brief, final comment on this matter: in this instance, it is worth mentioning certain additional circumstances that could serve as meaningful clues to support the proposed interpretation. First, I would like to point out that ironic reduction is generally one of the main defining mechanisms of the rhetorical strategy employed in the novel. There are passages that play a similar role to that of the visual representations by, for example, referring the reader to the perspective of a naïve observer through a reduction of the language to a behavioristic description of physical data, which, as in the case

36 Some critics (see, for example, Charles Russell, "The Vault of Language: Self-Reflective Artifice in Contemporary American Fiction," Modern Fiction Studies 20 (1974)) were willing to consider the "distance between words and phenomena" (ibid., 351) as one of the main determinants of the artistic formation represented by the likes of Vonnegut.

37 Compare this passage with the interpretation of Vonnegut's novels as examples of a particular affirmative parodical practice that explores the limits of "forms of meaningful action" in the study by Harriet and Irving Deer, "Satire as Rhetorical Play," Boundary 5 (1977): 711-722. 
of the visual depiction, cleans the object of any perceptive traces and meanings added through the process of social semiosis. ${ }^{38}$ The revolver, for instance, is torn from the realm of moralistic rhetoric and persuasive aestheticization through both an iconic recoding and the use of a naive definition: "This was a tool whose only purpose was to make holes in human beings." 39 Second, the supposition regarding the demythologizing quality of the image is also encouraged by the infantile visual style of the author's drawings. The destabilization of the narrative code is thus accomplished with the support of the potential within the code itself, while the questioning of existing stereotypes occurs by exploiting the stereotype that grants the childlike gaze the ability to discover that the emperor has no clothes. Nevertheless, iconic signs seem particularly predestined to semiotic sabotage, as they belong to the category of "weak" codes (maintaining, some would claim, the status of a semiotic hypothesis) and do not result in an alternative categorization of phenomena, but rather - by relying on likeness (even if it is conventionalized) rather than classification - merely indicate semiotic potentiality, encouraging many competing perspectives on the object.

The image is thus highly privileged as a sign that remains closer to reality, more neutral than the word, and, by the same token, less susceptible to symbolic abuse and falsification. This characterization of different types of signs, however, is conditioned upon the narrative strategy, which is associated with a specific axiological perspective. Vonnegut's novel clearly elevates the realm of the somatic experiences of the common man, who - to borrow a term from a Morris Dickstein essay - "knows in his gut that all ideals" 40 are worthless and treats them as abstract hypostases. ${ }^{41}$ In this prose, the lofty ideas and accomplishments of "high" culture are predominantly depicted in burlesque tones, while the perception of the direct, everyday experience is treated as the

38 This quality has been observed by critics and recognised as one of the most important features of the writer's style. See, for example, Morris Dickstein's remarks on the "flat and factual" tone of Vonnegut's novels, which serves to paint an image of a (sometimes irritating, by the critic's own admission) "wise simpleton" ("Black Humor and History: Fiction in the Sixties," Partisan Review 43.2 (1976): 197).

Vonnegut, Breakfast of Champions, 47

Dickstein, "Black Humor and History," 191.

One might safely include Vonnegut among the circle of writers that value the areas of the "material bodily lower stratum" (a term I borrow from Bakhtin) and explore a quasi-carnivalesque inversion of hierarchies. This assumption finds support in the first of the bi-codal interjections, one that contains a manifest of sorts: "To give an idea of the maturity of my illustrations for this book, here is my picture of an asshole" (Vonnegut, Breakfast of Champions, 13). 
only relatively effective shield against the destructive effects of social mythologies and cultural alienation.

A completely different relationship can be observed between the word and the image in the case of a literary work that refers to a somewhat different world view. The particular use of drawings in Antoine de Saint-Exupery's The Little Prince ${ }^{42}$ essentially results in the questioning of iconicity as a mode of representation. ${ }^{43}$ The imposition of a particular reference onto arbitrary pictographs tears the relationship of likeness from its objective anchors and essentially makes the reference conditional on subjective perceptions and the unrestrained choices of the subject. Thus the analogous nature of the image, which stabilizes the phenomenon in its given form, gives way to provisional associations and dynamic symbolic relationships. On the other hand, the individual sign, while retaining its uniform substantive form, can become a space in which alternative interpretations collide, appearing, for example, as either a snake or a hat ${ }^{44}$ (incidentally, the author employs the same mechanism of aspectual perception and gradable iconicity demonstrated by Ludwig Wittgenstein in his famous duck-rabbit drawing). It is worth noting that, in this case, the image operates similarly to symbolic signata, as it is subject to a certain homonymy that conditions its semantic fulfillment on the action of the verbal context and communicative environment.

Yet the questioning of signification through likeness in The Little Prince goes even further. In the famous passage involving the drawing of a sheep, subsequent illustrations of the supposed animal are rejected - in the course of negotiations between the narrator and the character - as failed, unsuccessful representations that obscure the individual nature of the original and artificially force its unique qualities into the mold of well-worn perceptual clichés. ${ }^{45}$ When a depiction is finally accepted, it is one that does not involve obvious analogies, and merely alludes to the very existence of its model. Considering the parabolic nature of the work, we may look for more general premises behind such a decision and understand the semiotic game described above as a pretext for sketching a certain anthropological design. The narrative of the book derives its dynamics from the tension between the desire to semiotically represent the Other (the sheep, in this case) and the fear of alienating appropriation. Actual representation thus turns out to be possible

\footnotetext{
42 Antoine de Saint-Exupery, The Little Prince (Ware: Wordsworth Classics, 1995).

43 In this passage I make use of the inspiring remarks of Prof. Teresa Dobrzyńska and Prof. Albena Chranova

44 de Saint-Exupery, The Little Prince ${ }_{t} 10$

45 Ibid., 14 .
} 
only when we abandon the creation of images of the Other and the reification of its qualities through a specific visual characterization, and merely outline the space in which this Other could spontaneously present itself, unbridled by our expectations and perceptions. In result, the visual code is harnessed by the narrative commentary into performing an iconoclastic function and, paradoxically, is turned against itself. The iconic elements dispersed throughout the book form an arrangement of negated signs that are summoned, in a sense, as examples and criticised as blunt objects associated with the oppressive power of the gaze.

\section{5.}

It could thus be assumed that Breakfast of Champions and The Little Prince each represent radically opposite narrative strategies: from the privileging of the image as a substitute for experience, to the critique of iconic likenesses as a specific form of reification. Between these two clearly polarized perspectives there can also be found certain intermediate solutions involving a more ambivalent approach to visual representation. One example of such an ambiguous stance is the latest (and, according to the subtitle, "illustrated") novel by Umberto Eco, The Mysterious Flame of Queen Loana, ${ }^{46}$ which problematizes the very opposition between iconic and symbolic signs. The author (quoted above as an expert in the field in question, and now appearing as the object of our analysis) tells the story of the antiquarian book seller Yambo who suffers partial memory loss as the result of an accident, retaining only his encyclopedic knowledge while losing all ties with personal memories. In an attempt to recover his lost identity, he spends his days poring over the books of his childhood, searching for any familiar signals that could reify his past experiences. Because visual messages comprise a majority of the texts read by the author, and are included as reproductions in the novel itself, the narrative eventually turns into an elaborate essay on the multiple meanings of the cited images. This discursive section of the book is so expansive that the images used within - among them encyclopedia illustrations, postage stamps, posters, postcards, comics, the covers of adventure novels, propaganda leaflets, etc. - focuses the majority of the reader's attention for an extended period of time and nearly rises to the rank of the main protagonist of the story (this expansive commentary was in fact the reason for the book's lukewarm reception among some of the critics, who complained about the less-than-coherent connection between the analysis and the plot, the privileged position of semiotics

46 Umberto Eco, The Mysterious Flame of Queen Loana: An Illustrated Novel, trans. Geoffrey Brock (London: Secker \& Warburg, 2005). 
at the expense of the narrative, and the rather unsuccessful disguising of the implicit autobiographical dimension of the investigations).

In subsequent chapters, Eco presents his readers with more illustrations, clippings, and reproductions that make up the home archive of the main character (and, at the same time, the narrator, and probably that of the author's own spokesman), while also displaying the cultural determinants of the image and the myriad ways in which it is entangled in the realm of social discourses and notions. The meaning of individual visual representations cannot be deduced on the basis of purely optical similarities, but rather, as it turns out in almost every instance, based on their dependence on various codes, customs, stereotypes, ideologies, and, finally, the circumstances of their reception. ${ }^{47}$ The semiotic reinterpretation of similar signs begins with the very first illustration, in which the main character attempts to depict Napoleon, at the request of a doctor. ${ }^{48}$

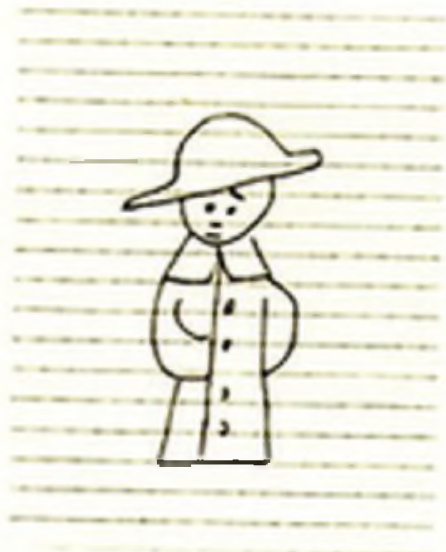

As it turns out, the likeness of the famous emperor bears more resemblance to a pictograph of sorts rather than a faithful portrait, as it refers not to a "natural likeness," to the visual qualities of the object, but rather to the

47 The peculiar "discursivisation" of the images appears to be aided by the fact that in Eco's work all visual interjections are narratively motivated by the conditions in which the text is read and, by the same token, are in a sense subordinated by the speech of the narrator who decodes their meaning (in contrast to Vonnegut's novels, in which images are introduced based on the author's arbitrary decisions and where representation is conditioned upon the modulations of the communication channel). 
attributes that stem from our knowledge of the subject, attributes ingrained in our semantic memory. Thus, this is a typical example illustrating Eco's theoretical thesis, which states that:

if an iconic sign shares attributes with something, it is not with the object itself, but with the model that governs our perception of the object; it is constructable and recognizable through the same thought processes that we undertake to construct a given concept, regardless of the substance in which the mutual relationship materialises. ${ }^{49}$

Here the author assists the reader in this task by having one of the characters explain the significance of the event: "You drew your mental scheme of $\mathrm{Na}$ poleon - the tricorne, the hand in the vest."50

Elsewhere, the change in the context of the reading produces a significant shift in its connotation: for example, a visually-motivated likeness is called into question in the case of a postage stamp collection. The images reproduced in this passage could essentially be regarded as iconic representations of various exotic places or landscapes ("the houses of Baghdad," "a Guatemalan landscape," "a map of the Fiji islands"51), as nearly ideal realizations of visual signs. Yet the narrator clearly emphasizes that for him, they make up a phantasmatic imaginarium, a "receptacle of oneiric images" rooted in his personal obsessions. Not representing any objects familiar to him through his own experience, the signs signified primarily though associations with the books of his youth, with the world depicted in adventure novels, and by belonging to the reality of the character's youthful dreams and notions. The pictures on the stamps thus refer to written texts, to popular stories and stereotypes of exoticism, and also to private associations and imagined representations. Multiple references are cited, yet none form any stable, motivated relationship, none achieve the status of an objective model. This contextual approach to the meanings of an image makes is articulated most evidently when the narrative focuses on propaganda messages dating back to the period in which the dominant ideology was that of fascism. The writer demonstrates, for example, how postcards bearing caricatures of Jews and Blacks reinforced racist prejudices by exploiting popular notions about the natural motivation behind the image. 52

49 Eco, Nieobecna struktura, 136.

50 Eco, The Mysterious Flame of Queen Loana, 22

51 Ibid., 254, 256

52 lbid., 188 

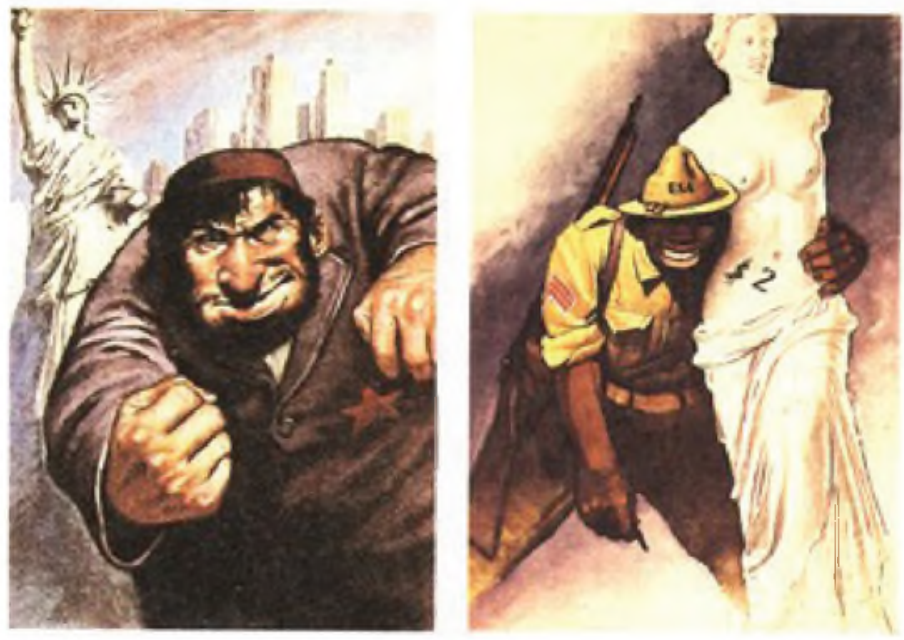

Only when confronted with specific wartime experiences and the circumstances following the war do the characters in the novel verify their previous notions, perceiving the inadequacy of well-known images and discovering the striking dissimilarity between the sign and the apparent model. The recognizability of the image turns out to be not so much a derivative of the simple, spontaneous perception of visual stimuli as it is a function of certain beliefs that shape reality in a specific manner. ${ }^{53}$ One can easily notice that, despite their variety, in all of these cases the attention of the writer is rarely directed towards individual iconic signs (nevertheless treated as "semata" belonging to different perceptual codes that do not refer to any supposed natural likeness), focusing instead on iconograms, or codified arrangements of signifiers that connote certain webs of notions and convictions. Their decipherment occurs through a peculiar form of "deiconisation" of the images while reading, which in turn reveals their conventionalized, quasi-symbolic semantic status.

53 This naturally raises the question of the interventional role of a narrative strategy that is apparently intended to be an implementation of the "semiotic guerrilla warfare" proposed by Eco: "to change the circumstances influencing the readers' choice of the code governing their reception." (Nieobecna struktura, 406-407). Such an interpretation allows us to treat The Mysterious Flame of Queen Loana as a novelistic illustration of the author's theoretical postulates. This, however, does not exhaust the issue, as the cited representations are additionally tied up in the dialects of truth and pretense, decadence and vitality, representation and ineffability. I will not explore this subject further, due to a lack of space. 
6.

In the last three novels mentioned above, we witness the near removal or, to use a more careful term, the neutralisation of the icon's primary meanings, the marginalization of the referential association, which becomes pretextual and incidental. However, the series of visual representations is used in such a way that, without changing its denotation, it becomes a medium for new meanings that emerge from the overall structure of the message. It can thus be assumed that it is not the iconic sign itself, but the manner in which it is used in a given context, that co-creates the meaning of the message. A similar pattern can nevertheless be observed, though likely to a lesser extent, in all of the other literary works mentioned. Practically none of the examples discussed above emphasize the purely artistic qualities of the icon, which does not serve a pictorial purpose in the traditional sense, nor does it affect us with its visual qualities, but instead enters an abstract game of concepts, thus becoming a medium for categorical qualifications and stereotypical cultural characterisation. Only superficially do the cited images resemble traditional illustrations: the former differ from the latter in that they do not serve any autonomous aesthetic or representative function, and are thus by definition essentially devoid of any particular artistic value. They do not explain their purpose in the mimetic plane of representation nor in the context of the pictorial conventions that govern contemporary art, and elude description in terms of art criticism or history. They do, however, belong to a greater semantic complex in which objective references are dominated by metatextual and pragmatic meanings. Rather, the direction of such semanticisation is determined mainly by the manner in which the drawings are combined with the verbal layer, through the use of explicitly expressed content, stylistic devices, and compositional choices. It is this linguistic context of the iconic interjections - their "verbal interpretant" 54 - that enables us to guess which of the connotations of the likeness in question will be relevant and useful within the frame of a given message. The word also allows us to specify the communicative status of content connoted in this manner, as well as its hierarchical position and modal characteristics (which determine, for example, whether given signs should be treated as the authoritative media of narration, traces of the author's own presence, or quotes from the popular iconosphere that have been subjected to critical reflection). Once processed in this manner, the image ceases to be a mere likeness, a simple "view of a thing,"55 and becomes a medium for diverse information, a textual phenomenon of sorts.

54 Maria Poprzęcka, Czas wyobrażony. O sposobach opowiadania w polskim malarstwie XIX wieku (Warszawa: Wydawnic twa Uniwersytetu Warszawskiego, 1986), 67. 
In his excellent study on intertextuality, Laurent Jenny treats iconic enclaves as just such an example of associations between statements, and simply considers the signs used therein as counterparts to purely linguistic elements. He posits that:

images, even when they exist within the body of the text - among sequences of lines - assume an ideographic character that brings them closer to verbality; they become directly translatable substitutes of a word. [...] The image can be likened to typography and the manner in which it is interpreted. It is deficient not only in visual terms, but also in that it has been pushed into a sentence that removes all of its value save for the symbolic, and incorporates it into its syntax. ${ }^{56}$

Despite its identification of the dominant role of verbal context and the ideographic status of visual signs, this perspective seems overly simplified and reductionistic. Though the claims regarding the necessary inclusion of the icon in the syntagma of the statement and the reduction of the textual gap separating the semiotic statuses of the image and the word seem convincing, I do not believe this is a matter of literal, straightforward translatability (in most cases, at least). The dissimilarity of the signifying substances and semantic functions calls for a more elaborate conclusion. There are undoubtedly certain obstacles associated with the interpretation of iconic signs which do not fit into the repertoire of standard devices used to build connections in discourse: they lack certain propositional content, they do not quantify events, they essentially do not support the contiguity of coreferential associations, nor do they automatically become part of the thematic and rhematic order of the message. Thus, when such a combination of words and images appears in a literary work, the normal process of reading is interrupted and we as the receivers encounter a certain resistance which cannot be overcome through the use of our standard readerly competence. Our understanding of the encountered arrangement is conditioned upon finding its motivation, the discovery of the premises justifying the choice of such a mode of presentation, and the formulation of the lines of reasoning that lead to a hypothesis that reconciles incommensurable systems of meanings (this plane of the image's action can be described as the enthymemetic level of the reception of visual messages, to borrow a phrase from Eco). ${ }^{57}$ This combination of codes is thus

56 Laurent Jenny, "Strategia formy," trans. Krystyna Falicka and Jerzy Falicki, Pamiętnik Literacki, 1 (1988): 283

57 Eco, Nieobecna struktura, 183. The term, of course, is based on the (not entirely precise) concept of enthymemes as "logical syllogisms" (ibid., 101). 
not merely a simple sum of the visual references and informational content in the judgment (as in the case of a rebus, for example), but is formed by the layering of two orders and encompasses the content suggested by such an unusual fusion. As there exist no routine rules governing the decipherment of similar arrangements, the process of reception must each time undergo a temporary communication crisis phase that results from the collision of incommensurable planes of meaning and different methods of reading. An image that operates within the space of paradigmatic relations must find its place in the syntagmatic structure of the text and determine its position in the linear flow of subsequent passages. ${ }^{58}$ The reader should therefore step outside the confines of the parallel bonds of likeness and consider what the very act of recognizing the existence of such relations can contribute to the gradually expanding story. What is more, the visual sign, as is often emphasized, refers to a concrete thing and the past, mainly utilizing the resources of our past experiences, while the symbolic code relies on the anticipation of possible states and entails a rationalization of thought. An important step involved in the semantic interpretation of visual enclaves within a work of literature can thus be the translation of iconic elements into symbolic linguistic signs; a translation that is not limited to the isolated name of the object, but one that takes the form of a discursive explication of the depictions (i.e. a judgment, a more elaborate explanation, or a line of reasoning). 59

The above study should be expanded to include at least an outline of the typology of specialized semantic functions served by the visual elements considered to be components of a literary work. At this point, however, it would likely be difficult to compile such a catalog, due to the extensive contextualization of the semantics of individual arrangements and their strong ties to the peculiarities of a given author's strategy. Perhaps, with time, as the popularity of heterogeneous visual-linguistic messages grows, there will emerge certain recognizable varieties of such intercodal semantic relations, but at present the reconstruction of the meanings of given icons cannot occur without a consideration of the nature of individual idiolects, and ought to indicate the diverse existing series, which are often divergent, autonomous, or intersecting. One

58 Peirce also emphasized that the image can signify, but is not in itself capable of conveying specific information (Peirce, What is a Sign?, 7), and that every signifying element can only acquire a communicative function once it has been included in the syntagma of a statement once it has been combined with a predicate, forming with it a judgment that contains some propositional content (Peirce, ${ }_{r}$ The Nature of Meaning, ${ }_{r}$ in The Essential Peirce, 220).

59 See, for example, Jakobson, "W poszukiwaniu istoty języka," in W poszukiwaniu istoty języka, trans., ed. Maria Renata Mayenowa, vol. 1, (Warszawa: 1989), 133; Mayenowa, Porównanie niektórych możliwości tekstów słownych i wizualnych ikonicznych, 177; Mitosek, "Słowo ikoniczne?," 45. 
may observe, however, that the visual insertions described above primarily function as model representations of culturally-marked subcodes equipped with certain personal, social, axiological, ideological, and historical characteristics. In result, the referential values stemming from the iconic structure of the sign are overshadowed by the content typically associated with symbolic signs, along with the meanings implied by the collision of incommensurable semantic fields. The interpretation of multicodal messages is thus synonymous with the integration of the disrupted coherence of the text, requiring the receiver to examine the unstated motivations of similar juxtapositions and to propose some hypothesis to explain the overall meaning of the statement. Meaning-creating processes involving pictorial signs therefore rarely occur on the level of purely iconic references, but rather - though initiated by references to such elements and relations - expand beyond the narrow range of objective recognition and are determined on the iconographic, tropological, and enthymemetic planes, or the areas in which the visual and linguistic layers co-operate. 